\title{
Elder abuse: actions and suggestions by Primary Health Care professionals
}

\author{
Violência contra o idoso: ações e sugestões dos profissionais da Atenção Primária à Saúde
}

Violencia contra los ancianos: acciones y sugerencias de los profesionales de la Atención Primaria de Salud

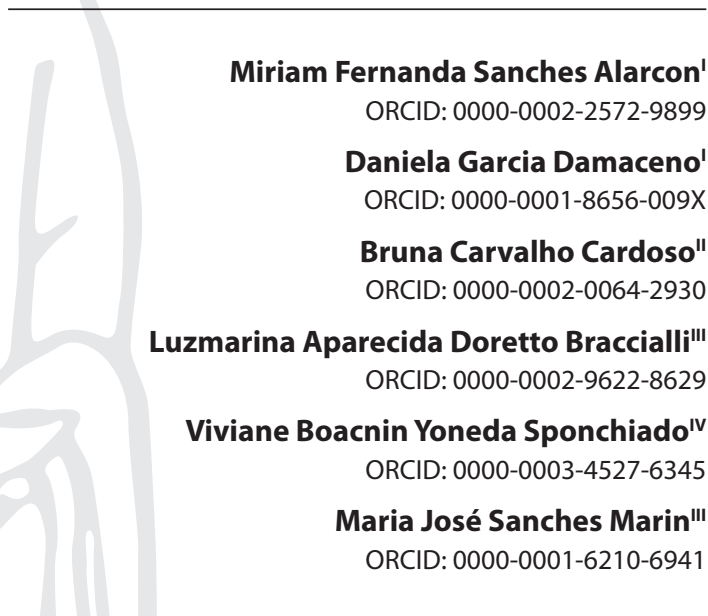

'Universidade Estadual Paulista "Júlio de Mesquita Filho". Botucatu, São Paulo, Brazil.

"Pesquisadora independente. Marília, São Paulo, Brazil. "II Faculdade de Medicina de Marília. Marília, São Paulo, Brazil. "Nelegacia de Polícia de defesa da mulher de Marília. Marília,

São Paulo, Brazil.

How to cite this article:

Alarcon MFS, Damaceno DG, Cardoso BC, Braccialli LAD, Sponchiado VBY, Marin MJS. Elder abuse: actions and suggestions by Primary Health Care professionals.

Rev Bras Enferm. 2021;74(Suppl 2):e20200263. doi: http://dx.doi.org/10.1590/0034-7167-2020-0263

\section{Corresponding author:}

Miriam Fernanda Sanches Alarcon

E-mail: miriam@uenp.edu.br

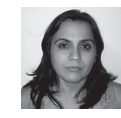

EDITOR IN CHIEF: Antoio José De Almeida Filho ASSOCIATE EDITOR: Priscilla Broca

\section{ABSTRACT}

Objective: to analyze the actions and suggestions of Primary Care professionals in relation to elder abuse. Method: this is a research with a qualitative approach based on the realization of focus groups with professionals from Primary Health Care in a city in the interior of São Paulo. The methodological stance of Hermeneutic-Dialectic thinking (HD) was adopted. Results: two themes were listed: Actions taken by health professionals and Suggestions for improving care for elderly victims of violence. Final considerations: professionals emphasized the need to implement new resources and improve the functioning of existing ones, so that comprehensive care is possible, in order to prevent and intervene in the important social and public health problem that violence represents.

Descriptors: Aged; Aging; Violence; Primary Health Care; Family Health.

\section{RESUMO}

Objetivo: analisar as ações e sugestões dos profissionais da Atenção Primária em relação à violência contra o idoso. Método: pesquisa com abordagem qualitativa a partir da realização de grupos focais com profissionais da Atenção Primária à Saúde de um município do interior paulista. Adotou-se a postura metodológica do pensamento Hermenêutico-Dialético (HD) Resultados: foram elencadas duas temáticas: Ações realizadas pelos profissionais de saúde e Sugestões para melhoria da atenção ao idoso vítima de violência. Considerações finais: os profissionais enfatizaram a necessidade de implementar novos recursos e de melhoria no funcionamento dos já existentes, para que seja possível o atendimento integral, com vistas a prevenir e intervir no importante problema social e de saúde pública que a violência representa. Descritores: Idoso; Envelhecimento; Violência; Atenção Primária à Saúde; Saúde da Família.

\section{RESUMEN}

Objetivo: analizar las acciones y sugerencias de los profesionales de Atención Primaria sobre la violencia contra los ancianos. Método: investigación con enfoque cualitativo basada en la realización de grupos focales con profesionales de la Atención Primaria de Salud en una ciudad del interior de São Paulo. Se adoptó la postura metodológica del pensamiento hermenéutico-dialéctico (HD). Resultados: se enumeraron dos temas: Acciones realizadas por profesionales de la salud y Sugerencias para mejorar la atención a los ancianos víctimas de violencia. Consideraciones finales: los profesionales enfatizaron la necesidad de implementar nuevos recursos y mejorar el funcionamiento de los existentes, de manera que sea posible la atención integral, con miras a prevenir e intervenir en el importante problema social y de salud pública que representa la violencia.

Descriptores: Anciano; Envejecimiento; Violencia; Atención Primaria de Salud; Salud de la Familia. 


\section{INTRODUCTION}

Worldwide, the increase in the elderly population is significant. In Brazil, there are growing demographic projections for the coming decades, and for 2060, the forecast is that the population over 65 years old will be approximately $25 \%$ of the total inhabitants ${ }^{(1)}$. Longevity takes on an important place in public policies and in society, since, in this age group, individuals are more vulnerable to changes in health status and dependencies for Activities of Daily Living $(A D L)^{(2)}$, making also exposed to situations of violence, which represents an important public health problem given its magnitude and transcendence.

In this scenario, the Brazilian National Policy for Elders (Política Nacional do Idoso), created in 1994, was relevant, since it ensures, among other aspects, social rights for elderly people; however, it does not specify actions against violence. In 2003, with the approval of the Senior Citizen Statute, there was a reinforcement of protection against violence, given the vulnerability and dependence existing among elderly people. In the 2006 Pact for Health Guidelines, it was defined as one of the priorities to make feasible the actions foreseen in the Brazilian National Elder Health Care Policy (Política Nacional de Atenção à Saúde do Idoso), among them the fight against domestic and institutional violence, the curbing of abuse and exploitation of elderly people ${ }^{(3)}$.

Even with such initiatives aimed at the protection and guarantee of human rights, elder abuse is a complex, multifaceted problem that occurs essentially inside homes. Thus, it is extremely important that professionals and managers keep themselves updated and trained in relation to violence, so that they can identify the victimized elderly people and adopt the appropriate behaviors, in order to avoid its consequences ${ }^{(4)}$. The health service is a place considered essential for recognizing cases of violence, with nursing professionals highlighted in developing interactive practices and comprehensive care, with repercussions on education and health promotion ${ }^{(5)}$. However, not all managers are able to express the proposal of the Brazilian National Elder Health Care Policy, despite recognizing elderly people as a priority for health services ${ }^{(6)}$.

Health professionals should take advantage of opportunities to approach elderly people and family members, as, at these times, they are able to investigate situations of violence that may occur with elderly people who seek health services, such as outpatient clinics, urgent and emergency services and, especially, Primary Health Care (PHC) services ${ }^{(4)}$. However, many professionals find it difficult to act in such a situation, especially when reporting, as they suffer threats from offenders ${ }^{(7)}$.

Professionals should promote an atmosphere of trust for elderly people and respect their decisions, also considering whether they are in full exercise of mental capacity, providing correct referral to each situation, paying attention to the satisfaction of the physical, social and emotional needs of each victim ${ }^{(8)}$.

Health professionals, in most cases, are aware of the situation of elder abuse only when they provide indications of such situation or through information from Community Health Workers, who identify the case in the neighborhood ${ }^{(7)}$.

PHC professionals occupy a prominent place for the development of actions and suggestions in the face of violence, as they are the gateway to discovering violence, most of the time, by creating bonds with the victims and with people around them. Thus, they are more easily able to propose suggestions for improving the quality of life of elderly people victims of violence.

In this context, the study aimed to answer the questions: what are the actions currently performed by PHC professionals in the face of elderly people who suffer violence? And what are the suggestions for improving the quality of life of this elderly victim?

\section{OBJECTIVE}

To analyze the actions and suggestions of Primary Care professionals in relation to elder abuse.

\section{METHOD}

\section{Ethical aspects}

The research complied with the specifications of Resolution $466 / 2012$, being approved by the Research Ethics Committee with Human Beings of the Faculty of Medicine of Marília. All of them consented to participate after signing an Informed Consent Form. To preserve anonymity, the codes G1, G2, G3 and G4 and P.A1 to P.A9 (Professional Action) and P.S1 to P.S9 (Professional Suggestion) were used.

\section{Theoretical-methodological framework and type of study}

With a qualitative approach, for data analysis, the methodological stance of Hermeneutic-Dialectic (HD) thinking was adopted. Hermeneutics is considered as a methodological tool that triggers possibilities of interpretation of the text, going from the objective to the abstract, collecting meaningful information through a constant dialogue about reality ${ }^{(9)}$. Dialectics, in turn, allows a critical look at everyday relations and actions, involving dialogue and questioning in the search for obscure and contradictory nuclei ${ }^{(10)}$.

\section{Methodological procedures}

\section{Study setting}

This study was carried out in a medium-sized municipality in the interior of the state of São Paulo, with an estimated population, in 2017, of 235,234 inhabitants, and which currently has 37 Family Health Strategy (FHS) units and 12 Traditional Basic Health Units (TBHU) ${ }^{(11)}$.

Professionals working in PHC participated in the research, being three FHS teams and one from TBHU, which were selected from the data of a geoprocessing carried out from the reports of occurrences referring to elder abuse, registered in the police station of the municipality in a six-month period. Therefore, those located in regions with a higher proportion of records of elderly people who suffered violence were elected.

\section{Data source}

The data were obtained through a focus group. As it is considered a technique based on the dialectic of human processes 
Elder abuse: actions and suggestions by Primary Health Care professionals Alarcon MFS, Damaceno DG, Cardoso BC, Braccialli LAD, Sponchiado VBY, Marin MJS.

and groups, it makes it possible to collect information through discussions between participants, valuing the interaction between them and the complementarity of opinions, concepts and experiences $^{(12)}$. Four focus groups were held, one in each selected unit, totaling 30 participants, with nine people in the first and second focus groups, and six in the others. Among the professionals of the units, four are nursing assistants, 13 are Community Health Workers, two are nursing technicians, one is a general services assistant, two are dentists, two are nurses, two are doctors, one is an endemic control agent and one is an office assistant. The research participants were 26 females and four males, aged between 27 and 60 years and with professional experience from three months to 17 years.

\section{Data collection and organization}

Data collection was carried out from November to December 2018. The composition of the focus groups occurred by inviting the teams from the previously selected units. To this end, telephone contact was made with nurses in charge of the units, who, after taking the request to the teams' knowledge and obtaining their consent, confirmed their participation for the person in charge of the research. At that time, the date, place and time of the focus groups were scheduled, which occurred at the time of the meeting held weekly by the teams.

Professionals who were working on the focus group day were included. Professionals removed from service for any reason during the time of the survey were excluded. There was no refusal by professionals to participate in the study.

Focus groups were developed in a room at the health unit, moderated by a researcher and two observers with experience in the technique. The moderator mediated the discussion and used strategies that favored the debate. The observers were responsible for noting the dynamics of the group and assisting the moderator.

To promote reflection by professionals on the subject, the researchers took printed images, available in the media, of elderly people who were victims of violence. For the focus group participants, a script was used with the following questions: how did you feel looking at these images? Have you faced similar situations in your work? If so, how was it? What have you done? What is the best way to assist an elderly patient who is a victim of violence? Focus group discussions were recorded. After full transcription, the material was deleted.

\section{Data analysis}

For data analysis, from the methodological stance of HD thinking. The search for the meanings underlying participants' narratives was carried out by understanding the meaning of the facts that made up the dynamics of the experienced process, considering the testimony as a result of the social process, and the knowledge, resulting from multiple determinations, but with specific meaning $^{(10)}$.

In data analysis, the following steps were performed: data organization, classification, and interpretation ${ }^{(10)}$. The chosen analysis must respect the temporality and maturity present in the speeches of the participants and use HD to understand the data ${ }^{(9)}$.

\section{RESULTS}

From analysis of the information obtained in the focus groups, two central themes emerged in the meanings underlying professionals' statements: Actions taken by health professionals and Suggestions for improving care for elderly victims of violence.

\section{Actions carried out by health professionals}

Regarding the actions of health professionals in relation to elder abuse, three thematic axes emerged: Carrying out referrals to others; Caring for elderly people and family members; Reporting.

As for the action of $\mathrm{PHC}$ professionals, the interviewees indicate that they make referrals to another service in order to expand the possibility of resolving cases of elderly people who suffer violence, which includes CRAS, Day Center for elderly people and the Center for Family Health Support staff (NASF - Núcleo de Apoio à Saúde da Familia), with the understanding that, together, they achieve greater resolution. However, they report difficulties, especially in relation to counter-referral, because, often, both team and users are unaware of the result of the actions of other services.

Wow [...].I think he called everyone that was possible! [...] It was NASF, it was the Elderly Council. Everything that was within reach was called. $(\mathrm{G} 2, \mathrm{P} 4)$

[...] when we see that it will not resolve, we call on CRAS to intervene. $(\mathrm{G} 3, \mathrm{P} 4)$

At the Day Center, we always call for help, but not in court. (G3, P1)

[...] Because today we don't even receive a counter-referral from anything, so we really do not know what happened and, many times, patients do not know what they solved, they are waiting for an answer from us [...]. (G4, P3)

Professionals also develop actions together with elderly people and family members by notifying cases of aggression, welcoming, talking and meeting with family members, scheduling appointments and home visits, aiming to direct care in both physical and psychological aspects. They consider that, in most cases, family members need support and awareness.

Generally, we notify you if you have an aggression case, welcome. Usually, when you see that there is a lack of family support, we try to talk to family members. (G3, P4)

What happens more is the neglect, sometimes, of people having to direct the family on how to take care of that elderly person. We have already met, with several families, a meeting with the children to direct and help them understand that it is their obligation to take care. $(\mathrm{G} 3, \mathrm{P} 1)$

[...] so, we offer consultation, visits, we take care of the physical part, the emotional part, but what to do more? How to end this violence? $(\mathrm{G} 4, \mathrm{P} 2)$

Professionals approach, among their actions, reporting, but they feel powerless and unprepared for that. They reported having knowledge of Call 100 by a professional from the police station. 
Elder abuse: actions and suggestions by Primary Health Care professionals Alarcon MFS, Damaceno DG, Cardoso BC, Braccialli LAD, Sponchiado VBY, Marin MJS.

Nobody had warned and, with that information, they feel more relaxed to report if necessary.

Ah, I think that, even I didn't speak at that time, I think that now there is this Call 100. I think the social worker at the police station who spoke, I didn't know I had this Call 100 is [...] so, I think, for people to be safer, but until then we haven't had any cases like that, at least we have witnessed. (G4, P4)

\section{Suggestions for improving care for elderly victims of violence}

This theme involves improving interpersonal articulation, establishing support services for elderly people, health education for aging, reducing bureaucracy in interventions and respecting autonomy.

As suggestions for improving care for elderly victims of violence, the importance of interprofessional articulation was emphasized, with conversation and discussion among professionals from different services that assist elderly people. Here are excerpts from the statements:

[...] yes, I think I would have to improve this intersectoral issue and be more open [...]. We do not receive counter-referrals [...]. (G2, P6)

[...] so, it was CRAS, it was CREAS, it was all levels that were assisting that family, so an elderly person, as it is a more difficult situation, I think it would have to be this way, to have this case discussion partnership. (G2, P6)

Participants cited the importance of a specific structure for welcoming elderly people, being a service that elderly people can trust and spend the day, like a daycare center, while family members go out to work. Or, after reporting a violence in which an elderly person needs to leave home, there should be a structured service for listening to this elderly person. Here are excerpts from the statements:

The city should have a shelter like this for elderly people, just like a day care center for children, it should have the same for an elderly person. (G1, P2)

[...] because, generally, when we know, elderly people have been suffering abuse for many years! I think that if I had this service here in the area of listening to what they want to say, in general, I think that it would prevent many diseases, many things [...]. (G3, P9)

[...] that she didn't even speak vaguely, having more vacancies, having more activities, I don't know, having things aimed more at elderly people. $(\mathrm{G} 3, \mathrm{P} 8)$

Professionals highlighted in the statements that some elderly people had difficulty in dealing with the limitations resulting from aging, as they always took care of their own lives. They suggested that guidelines be carried out to help more naturally accept the limitations of this phase of life.

Because it was a whole life like this, taking care of your own life, there comes a time when someone will tell you what you are going to do, then the person cannot see it. $(\mathrm{G} 1, \mathrm{P} 1)$
An elderly person, I say that the elderly are people who have always served, then they feel incapable, it's the worst thing for them [...]. $(\mathrm{G} 1, \mathrm{P} 1)$

Reducing bureaucratization of interventions was a suggestion recognized by professionals, as they emphasized the need for quick assistance to elderly victims of violence and emergency services that facilitate care in critical moments. Thus, an opendoor service, without much bureaucracy, for the referral of elderly people under abuse and needs to be welcomed, should be implemented.

I think there should be some service open doors without a lot of bureaucracy, that elderly people, or for the family to take directly, without having to go through so many things until they get to some service that offers [...]. (G4, P5)

Participants suggested that it is important to listen to the opinion of elderly people and respect their autonomy. Below follows the speech:

So, you don't have to reach out to elderly people and determine and say what they have to do, you have to ask if they want [...] they have to understand why it is important to do that there, because elderly people don't like to be sent, you determine an order for them. (G1, P1)

\section{DISCUSSION}

Health actions aimed at elderly victims of violence represent a major challenge for professionals in $\mathrm{PHC}$ health services. They face situations of great complexity that involve interfering in the context of life of elderly people and family members, the interprofessional relationship, the lack of resources and the very acceptance of elderly people in relation to their need for help.

In FHS, weaknesses are seen in caring for elderly people victims of violence resulting from the deficit in training health professionals and in articulating services with different technological densities, which highlights the importance of the proper functioning of the system of referral and counter-referral for an effective resolution of cases of violence ${ }^{(13)}$. According to Law 12.461/2011 ${ }^{(14)}$, when there is suspicion or confirmation of elder abuse, it should be referred to the Police Department, Public Prosecutor's Office, Municipal Council for the Elderly, State Council for Elderly People and/or National Council for Elderly People. However, although health service professionals have the task of making this referral, lack of counter-referral makes it difficult to support victims, as professionals are unable to effectively assist elderly people and family members.

Adequate organization of the demands required in each situation is necessary, so that professionals can provide comprehensive care for victimized elderly people ${ }^{(15)}$. In a study on the vision of Community Health Agents in their work process and coping strategies in their daily lives, they emphasized that health care networks are flawed. On a regular basis, specialized services, such as NASF and the Social Assistance Reference Center (CRAS - Centro de Referência de Assistência Social), receive referrals. However, in most cases, they verify the difficulty of articulation between 
professionals, which hinders the approaches involving the different knowledge necessary to assist elderly victims of violence, leaving professionals with a feeling of helplessness in the face of the lack of resolution of situations ${ }^{(16)}$, thus corroborating the findings of this present study.

In another study in the municipality of this research, the difficulty of communication between health services, through referral and counter-referral, was also pointed out as a problem, reinforced by a knowledge gap in undergraduate courses. It also points out that with the improvement of information flows and counterflows in health services, it would be possible to provide safe and effective care ${ }^{(17)}$.

Although elderly people are more vulnerable to changes in health conditions, especially in view of the condition of violence, there is a finding that, in $\mathrm{PHC}$, which constitutes the gateway to other levels of health care, there is no differentiation in assistance to elderly people and adults, which, added to the fragmentation existing in the functioning of the care network, leads to important limits in the assistance of this portion of the population ${ }^{(18)}$.

The need for an intersectoral and multidisciplinary approach in the care of elderly victims of violence, demonstrated in the present study, finds similarity when analyzing the health care of elderly people in general. As demonstrated in a study conducted in the capital of Ceará, to obtain assistance, elderly people go through five different care networks, facing queues, in addition to the lack of communication of the necessary information for continuity of care, especially in $\mathrm{PHC}^{(19)}$.

Added to this are the difficulties in implementing intersectorality found in a study that analyzed the flows of care for elderly people who are victims of violence in social, health and legal assistance services, which occurs due to the lack of communication and conflicts between services, especially in the face of difficult situations to solve ${ }^{(15)}$.

In this trajectory, to improve care for elderly people victims of violence, professionals suggest interprofessional articulation, since it provides better opportunities for care and guidance in simple, or even complex, cases of elder abuse, as it transforms experiences and knowledge of different professionals in response to practical situations, generating greater resolution and quality in health services ${ }^{(16)}$. Therefore, it is necessary to guarantee spaces for exchanging experiences and knowledge, with the establishment of horizontal and dialogued relationships ${ }^{(20)}$.

The interviewed professionals highlight the importance of interventions with the families of elderly people who are victims of violence, since, often, relationships with elderly people or between family members make it difficult to provide adequate care. The family is an integral part of the process and discussions and guidelines must take place during the process, as it is a complex social unit that has its own needs ${ }^{(21)}$. Knowing the family is fundamental to the sequence of solving cases, because, through historicity, it is possible to realistically plan the procedure to be followed, since the resolutions will fit the possibilities of the context ${ }^{(22)}$.

During the aging process, the occurrence of conflicts increases. There is an imaginary social prejudice about this age group, through which elderly people are treated with feelings of contempt and worthlessness. There are several facts that lead to elder abuse within the family context; however, in many moments, offenders do not perceive themselves as potential offenders, especially when they happen to have lived in a violent context in which they also suffered aggressions in their past. In this way, they learned to relate in such a way and to reproduce this behavior ${ }^{(23)}$.

Still, it is understood that health professionals should adopt different strategies to support elderly people, such as, for example, interventions, monitoring and other conducts that improve the quality of life of elderly people and their families and collaboration with other social reality problems ${ }^{(24)}$.

Reporting by Call 100 stood out in the speeches of the professionals in the study, as many emphasized that they feel safer when reporting in this way. Since they work and live in the area where they know their offenders, it is common to suffer threats from them. In 2017, 33,000 cases of elder abuse were reported through Call 100, with negligence followed by psychological violence being the most prominent ${ }^{(25)}$. Thus, the importance of this form of reporting is emphasized.

Call Human Rights - Call 100 is a free public telephone service that works 24 hours a day, 7 days a week. This is a communication channel between society and the Public Power - National Ombudsman for Human Rights - which focuses on conflict resolution and studies violations of rights. Reports made are analyzed and sent to the responsible bodies in order to seek appropriate measures. Furthermore, Call 100 proved to be an important means of dialogue and recording situations involving human rights violations, including elder abuse ${ }^{(26)}$.

The professionals interviewed in the present study emphasized the importance of having a place to welcome elderly people who suffer violence, either to spend the day or to stay longer. However, in Brazilian municipalities, there is a weakness in the strategy that can support elderly people, especially in cases where staying at home represents a risk to their health and life conditions. CRAS and Specialized Social Assistance Reference Centers (CREAS - Centros de Referência Especializados de Assistência Social) do not provide specific assistance to dependent elderly people, according to their needs ${ }^{(13)}$.

A visible problem with regard to support for elderly people is lack of coordination between society and government, of infrastructural investment and in consultation and guidance environments, as well as the ineffectiveness of public policies created to protect them from contexts and situations of violence ${ }^{(24)}$.

It is necessary to remember that care cannot often be expected to occur in the family context, especially when it comes to the socially less favored social classes. Members need to work to support their family and residence and care for elderly people generates overload in their activities, causing increased tiredness and stress and predisposing them to a situation of violence. Moreover, in $50 \%$ of cases of reports of ill-treatment against elderly people, caregivers are dependent on alcohol or illicit drugs ${ }^{(27)}$

The interviewees stressed the importance of health professionals welcoming elderly people victims of violence, creating an atmosphere of trust and respect for their wants and needs, considering their autonomy for decision-making. Therefore, it is necessary to start from the understanding that each situation has its own characteristics and is highly complex, as it involves the life story, the context in which it lives and the current physical, 
mental and psychological conditions. Therefore, the professional or the assistance team must adopt a comprehensive approach, in order to meet victims' real health needs ${ }^{(8)}$.

Another aspect that deserves to be highlighted is the need for social participation of elderly people in the community through leisure, with activities that provide the development of skills, allowing the elderly time for new learning and socializing in order to share experiences in this moment of change $\mathrm{e}^{(28)}$. Many study professionals stated that most elderly people spend a great deal of time at home and alone. Therefore, there is the importance of opening a space for leisure and socializing with other people in the community. In cases of elderly people who are unable to leave the home, home visits are of great importance, so they are able to have contact with professionals who can listen to them and comfort them in complicated moments ${ }^{(29)}$.

Providing spaces for reflections about the aging process is considered important by the interviewees, with a view to a greater understanding of this phase of life, including the possibilities and limits, in the dialogical perspective, so that they can expose their fears, prejudices and opinions ${ }^{(30)}$.

Health education promotes social transformation, and dialogue and discussion are essential measures for people's change and awareness, as both the voices of professionals and the population in general are heard, taking into account the knowledge and interest of each individual ${ }^{(31)}$.

Reducing bureaucracy is also a necessary condition for improving care for elderly people, aiming at providing easier access to the public service and generating effectiveness and efficiency, which can occur by simplifying the service provided by the public administration and improving services ${ }^{(32)}$.

Regarding elderly people's respect and autonomy, identified as a necessity by the professionals who participated in the focus groups, there is an understanding that personal autonomy and individual freedom of choice are essential aspects in the care of elderly people. Respect for autonomy is linked to the idea of individuals who make their own decisions about their own actions without being influenced by others. Therefore, caregivers must support decision-making and autonomy, so that, even with some degree of dependency, they can have the feeling of control of everyday life ${ }^{(33)}$.

Thus, there is a need for advances in policies aimed at elderly victims of violence through the participation of different social actors and intersectoral articulation, aiming at actions that provide better quality of assistance to these people.

\section{Study limitations}

The limitation of this study is the fact that it was carried out with professionals from a single municipality, which does not allow generalization of the results. However, the results contribute to important reflections on the theme and its relevance in the context of PHC.

\section{Contributions to nursing, health, and public policies}

The results of this study offer subsidies to expand the understanding and visibility of actions, as well as gaps in care, considering the complexity of nursing and health actions for elderly victims of violence. PHC professionals' suggestions for improving care for these people can support both the actions of professionals and the strengthening of public policies.

\section{FINAL CONSIDERATIONS}

This article sought to analyze PHC teams' actions and suggestions in relation to elder abuse.

As for the actions taken, the professionals interviewed indicated that they make referrals to other services for elder care, aiming to expand the possibility of solving cases and direct care to elderly people and family members, essentially through notification of cases of aggression, reception, conversation and meeting with family members and scheduling consultations and home visits, focusing on physical and emotional aspects. They also make reports of situations of violence through Call 100 as it is a mechanism that guarantees anonymity and provides security.

Professionals suggested improving interprofessional articulation, establishing referral flows and services for elderly people, where there is a welcoming and quality structure for elderly people to spend the day. They prioritized the reduction of bureaucracy in the reporting and the importance of health education in the search to make elderly people aware of the needs and limitations of this stage of life. They also suggest the reduction of bureaucratization of interventions by professionals, since elderly people who are victims of violence need quick assistance, in open service, which facilitates care in the face of the critical moment they are experiencing.

Thus, it appears that, although they manage to develop actions aimed at caring for elderly people victims of violence, based on the bond and longitudinality and considering the proximity that $\mathrm{PHC}$ professionals maintain with users, professionals also find important gaps in assistance. Thus, they suggest implementing new resources and improving the functioning of existing ones so that comprehensive care is possible in order to prevent and intervene in the important social and public health problem that violence represents.

\section{FUNDING}

Coordenação de Aperfeiçoamento Pessoal de Nível Superior (CAPES); Fundação de Amparo à Pesquisa do Estado de São Paulo (FAPESP) process n²017/17562-2.

\section{REFERENCES}

1. Instituto Brasileiro de Geografia e Estatística. A evolução da composição populacional por grupos de idade. Projeção de idosos acima de 65 anos para 2060[Internet]. 2020 [cited 2020 Jul 24]. Available from: https://www.ibge.gov.br/apps/populacao/projecao/index. html?utm_source=portal\&utm_medium=popclock\&utm_campaign=novo_popclock 
2. Bittencout P, Silva MA. Violência verbal contra idosos: palavras e silêncio marcados pela dominação. Rev Pretextos [Internet]. 2018[cited 2020 Jan 28];3(6):622-40. Available from: http://periodicos.pucminas.br/index.php/pretextos/article/view/15938

3. Ministério da Saúde (BR). Portaria no 2.528 de 19 de outubro de 2006. Aprova a Política Nacional de Saúde da Pessoa Idosa [Internet]. 2006 [cited 2020 Jul 24]. https://bvsms.saude.gov.br/bvs/saudelegis/gm/2006/prt2528_19_10_2006.html

4. Castro VC, Rissardo LK, Carreira L. Violence against the Brazilian elderlies: an analysis of hospitalizations. Rev Bras Enferm. 2018;71(Suppl 2):777-85. doi: 10.1590/0034-7167-2017-0139

5. Aguiar MPC, Leite HA, Dias IM, Mattos MCT, Lima WR. Violência contra idosos: descrição de casos no Município de Aracaju, Sergipe, Brasil. Esc Anna Nery. 2015;19(2):343-9. doi: 10.5935/1414-8145.20150047

6. Zen D, Leite MT, Hildebrandt LM, Silva LAA da, Sand ICPV. Políticas de atenção a idosos na voz de gestores municipais de saúde. Rev Gaúcha Enferm. 2018;39:e62502. doi: 10.1590/1983-1447.2018.62502

7. Oliveira KSM, Carvalho FPB, Oliveira LC, Simpson CA, Silva FTL, Martins AGC. Violência contra idosos: concepções dos profissionais de enfermagem acerca da detecção e prevenção. Rev Gaúcha Enferm. 2018; 39:e57462. doi: 10.1590/1983-1447.2018.57462

8. Camacho ACLF, Alves RR. Maus tratos contra os idosos na perspectiva da enfermagem: revisão integrativa. Rev Enferm UFPE. 2015;9(Suppl 2):927-35. doi: 10.1590/S0034-71672013000100020

9. Oliveira MM. Metodologia Interativa: um processo hermenêutico dialético. Interfaces Brasil/Canadá [Internet]. 2001 [cited Jan 29];1(1). doi: 10.15210/interfaces.v1i1.6284

10. Minayo MCS. O desafio do conhecimento: pesquisa qualitativa em saúde. 13 ed. São Paulo: Hucitec; 2013.

11. Instituto de Pesquisas e Economia Aplicada. Atlas do Desenvolvimento Humano no Brasil. IDHM Marília, SP [Internet]. 2010[cited 2020 Jul 24]. Available from: http://www.atlasbrasil.org.br/2013/pt/perfil_m/marilia_sp\#caracterizacao

12. Kinalski DDF, Paula CC, Padoin SMM, Neves ET, Kleinubing RE, Cortes LF. Focus group on qualitative research: experience report. Rev Bras Enferm. 2017;70(2):424-9. doi: 10.1590/0034-7167-2016-0091

13. Alcântara AO, Camarano AA, Giacomin KC, (Org). Política nacional do idoso: velhas e novas questões [Internet]. Rio de janeiro: IPEA; 2016 [cited 2020 Jan 31]. Available from: http://www.ipea.gov.br/portal/images/stories/PDFs/livros/livros/161006_livro_politica_nacional_idosos.PDF

14. Presidência da República (BR). Subchefia para Assuntos Jurídicos. Lei no 12.461 , de 26 de julho de 2011 . Altera a Lei no 10.741 , de $1^{\circ}$ de outubro de 2003, para estabelecer a notificação compulsória dos atos de violência praticados contra o idoso atendido em serviço de saúde [Internet]. Diário Oficial da União de 27 de julho de 2011. Brasília, DF: 2011. [cited 2020 Jan 31]. Available from: http://www.planalto.gov.br/ ccivil_03/_Ato2011-2014/2011/Lei/L12461.htm

15. Plassa BO, Alarcon MFS, Damaceno DG, Sponchiado VBY, Braccialli LAD, Silva JAVE, et al. Flowchart of elderly care victims of abuse: an interdisciplinary perspective. Esc Anna Nery. 2018;22(4):e20180021. doi: 10.1590/2177-9465-ean-2018-0021

16. Riquinho DL, Pellini TV, Ramos DT, Silveira MR, Santos VCF. O cotidiano de trabalho do agente comunitário de saúde: entre a dificuldade e a potência. Trab Educ Saúde. 2018;16(1):163-82. doi: 10.1590/1981-7746-sol00086

17. Fittipaldi Neto J, Braccialli LAD, Corrêa MESH, Moraes MMA, Tófano VAC. Referência e contrarreferência: ainda um problema entre os médicos. Temas em saúde. Vol. 19, n.6. João Pessoa, 2019.

18. Coelho LP, Motta LB, Caldas CP. Rede de atenção ao idoso: fatores facilitadores e barreiras para implementação. Physis. 2018;28(4):e280404. doi: 10.1590/S0103-73312018280404

19. Santos CTB, Andrade LOM, Silva MJ, Sousa MF. Percurso do idoso em redes de atenção à saúde: um elo a ser construído. Physis. 2016;26(1):45-62. doi: 10.1590/S0103-73312016000100005

20. Silva EM, Moreira MCN. Equipe de saúde: negociações e limites da autonomia, pertencimento e reconhecimento do outro. Cienc Saúde Coletiva. 2015;20(10):3033-42. doi: 10.1590/1413-812320152010.20622014

21. Grillo GPM, Marins AMF, Melo R. The family caregiver's discourse on the hospitalization of the elderly with Alzheimer's disease. Rev Pesqui: Cuid Fundam. 2017;9(4):1068-73. doi: 10.9789/2175-5361.2017.v9i4.1068-1073

22. Moore S, Kawachi I. Twenty years of social capital and health research: a glossary. J Epidemiol Community Health. 2017;71(5):513-7. doi: 10.1136/jech-2016-208313

23. Silva CFS, Dias CMSB. Violência contra idosos na família: motivações, sentimentos e necessidades do agressor. Psicol Cienc Prof. 2016;36(3):637-52. doi: 10.1590/1982-3703001462014

24. Mallet SM, Côrtes MCJW, Giacomin KC, Gontijo ED. Violência contra idosos: um grande desafio do envelhecimento. Rev Med Minas Gerais [Internet]. 2016 [cited Feb 3];26(Suppl 8):S408-S413. Available from: http://rmmg.org/artigo/detalhes/2188

25. Empresa Brasil de Comunicação. Agência Brasil. Direitos Humanos. Disque 100 registra 142 mil denúncias de violações em 2017. Idosos [Internet]. 2018[cited 2020 Feb 3]. Available from: https://agenciabrasil.ebc.com.br/direitos-humanos/noticia/2018-04/ disque-100-registra-142-mil-denuncias-de-violacoes-em-2017

26. Ministério Público do Estado do Amapá. Relatório Disque 100 - Disque Direitos Humanos de 2012 a 2015 [Internet]. Macapá; 2016. [cited 2020 Feb 4]. Available from: www.mpap.mp.br/images/infancia/Disque_100_RELATÓRIO_FINAL.pdf

27. Silva CFS, Dias CMSB. Violência contra idosos: perfil sociodemográfico dos familiares agressores, tipos de violência impetrada e motivações para sua ocorrência. Rev Gest Saúde [Internet]. 2016 [cited 2020 Feb 4];7(2):563-81. Available from: https://dialnet.unirioja.es/servlet/articulo?codigo=5555888 
28. Wanderbroocke AC, Wiedemann A, Bussolin C. Participação social e familiar de idosas vinculadas a um grupo de convivência de uma comunidade de baixa renda em Curitiba-PR. Salud Soc. 2015;6(3):212-22. doi: 10.22199/S07187475.2015.0003.00002

29. Schenker M, Costa DH. Advances and challenges of health care of the elderly population with chronic diseases in Primary Health care. Ciênc Saúde Coletiva. 2019;24(4):1369-80. doi: 10.1590/1413-81232018244.01222019

30. Cabral JR, Alencar DL, Vieira JCM, Cabral LR, Ramos VP, Vasconcelos EMR. Education workshops in health with elderly: a life quality promotion strategy. Rev Enferm Diag Cuid Promoç Saúde. 2015;1(2):71-5. doi: 10.5935/2446-5682.20150011

31. Rocha VD, Vieira SNS, Santos AT, La Longuiniere ACF, Vieira DS, Silva JM. Educação em saúde em um grupo de convivência da terceira idade: experiência vivenciada. Rev Inov Tecnol Ciên [Internet]. 2015 [cited 2020 Feb 10];1(1):173-80. Available from: http://periodicos.ftc.br/index. $\mathrm{php} / \mathrm{ritec} / \mathrm{article} / \mathrm{view} / 96 / 121$

32. Presidência da República (BR). Casa Civil. Notícias. Programa Brasil Eficiente vai modernizar gestão e simplificar acesso a serviços[Internet]. Brasília, 2017 [cited 2020 Feb 10]. Available from: https://www.gov.br/casacivil/pt-br/assuntos/noticias/2017/junho/ governo-prioriza-medidas-para-modernizar-gestao-e-simplificar-acesso-a-servicos

33. Fjordside S, Morville A. Factors influencing older people's experiences of participation in autonomous decisions concerning their daily care in their own homes: a review of the literature. Int J Older People Nurs. 2016;11(4):284-97. doi: 10.1111/opn.12116 